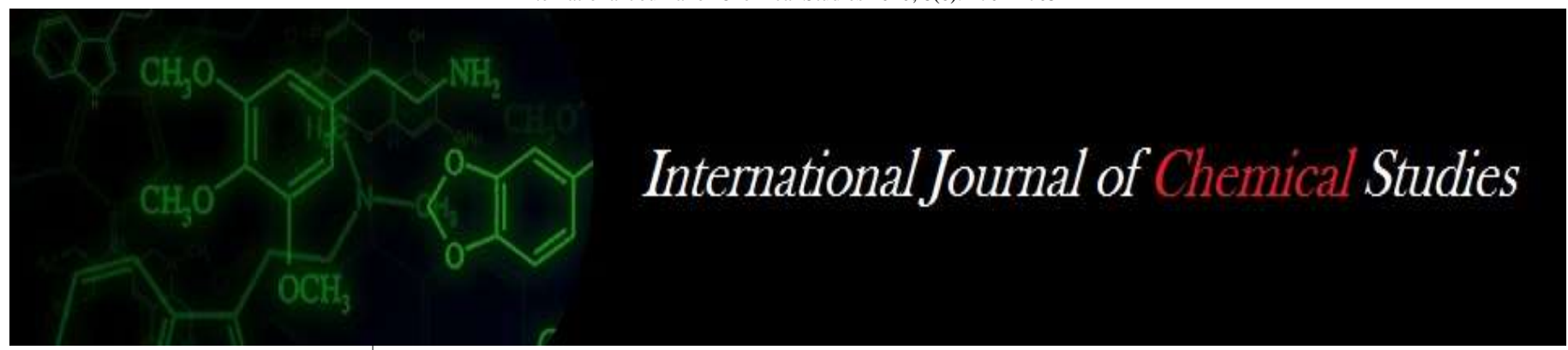

P-ISSN: 2349-8528

E-ISSN: 2321-4902

www.chemijournal.com

IJCS 2020; 8(6): 1702-1705

(C) 2020 IJCS

Received: 26-09-2020

Accepted: 10-11-2020

Gudikati Shashank Reddy Department of Agronomy, School of Agriculture, Lovely Professional University, Jalandhar, Punjab, India

Dr. Gurpreet Singh

Department of Agronomy, School of Agriculture, Lovely Professional University, Jalandhar, Punjab, India

\section{Response of bajra in its growth and yield attributes to integrated nutrient management}

\author{
Gudikati Shashank Reddy and Dr. Gurpreet Singh
}

DOI: https://doi.org/10.22271/chemi.2020.v8.i6x.11014

\begin{abstract}
Kumbu known as pear millet [Pennisetum glaucum (L.)] is one of the important millet crops for arid and semi-arid climatic condition and serves as poor man's staple source of food in short period relatively in arid regions of India. Pearl millet (Pennisetum glaucum L.) experiment was carried out at CCS Haryana Agricultural University, Hisar during 2009- 10 to study the outcome of integrated nutrient management where the results have shown that on inoculating seed with azotobacter increased both pant height and in total dry matter content. A study conducted to analyse fertilizer effect on pearl millet revealed that under semi-arid inceptisols, $100 \% \mathrm{NPK}+\mathrm{FYM}$ at 10 tha-1 $+\mathrm{Zn}$ at $25 \mathrm{~kg}$ ha-1 $+\mathrm{S}$ at $25 \mathrm{~kg}$ ha-1 recommended can help in getting maximum yields of Bajra. At the Agricultural Farm of Rajiv Gandhi South Campus, Banaras Hindu University, Barkachha, Mirzapur experiment was conducted to study phosphorus and zinc nutrients, their effect on overall nutrient uptake and quality in pearl millet. N, P and $\mathrm{K}$ content in grain and straw have been found to be increased from 1.56 to $2.02,0.773$ to $1.320,1.10$ to $1.97 \%$ and 1.11 to $1.41,0.23$ to 0.50 and 0.68 to $1.20 \%$, respectively. In Annamalai University, on the basis of experimental data significant results were recorded in the nutrient content, quality and highest nutrient content, protein content, protein yield and water productivity were observed with PHB-3 among all the experimented genotypes of bajra. It was also found that using vermicompost @ $500 \mathrm{~kg}$ ha-1 gave highest nutrient content, protein content, protein yield and water productivity over the rest of the treatments. Considering all approaches giving out their benefits, the best approach for maximising yields in bajra under arid conditions by maintaining soil properties would be the Integrated Nutrient Management approach.
\end{abstract}

Keywords: Azotobacter, nutrient uptake, biofertilizers, integrated nutrient management etc.

\section{Introduction}

Pearl millet (Pennisetum glaucum) is one of the important climate resilient millet crop which is mainly cultivated as a rainfed crop in dry land agriculture. It is also called as the "Power house of nutrients". India holds first position in the production of pearl millet in the world occupying about 7.32 million hectares with annual production of 9.18 million tons with average productivity of $1255 \mathrm{~kg} \mathrm{ha}^{-1}$. (Krisnaprabu, 2018) ${ }^{[5]}$. They can be utilised in various forms viz., food, feed, fuel, fodder and brewing. Millets are more nutritionally superior to wheat and rice as they have higher levels of protein, crude fibre and minerals and low glycaemic index, which is beneficial for diabetic and heart patients. Pearl millet grains contain protein (11-19\%), carbohydrates (60-70\%) and fat (4.6\%). It requires less water foot print and also less carbon foot print for its production. In the present scenario of rapid increasing obesity related problems in India, pearl millet has become one of the dietary interventions for obesity and weight management, because of which many people were opting the lower calorie and climate friendly foods like pearl millet. Owing to its importance in decreasing various lifestyle diseases, enhancing resilience and risk management in face of climate change, and ability to offer nutritional security, the Food and Agricultural Organization (FAO) has approved the India's proposal to declare the year 2023 as the International year of Millets. Even though as pearl millet crop provides several benefits, the production still needs to be enhanced to meet the huge demand. The productivity can be enhanced by adopting the improved production technologies, bringing more area under cultivation, proper nutrient management etc. The main reason for the lesser yield is mainly growing in rainfed conditions, and there is less emphasis on nutrient needs of the crop. The lack of irrigation in drought conditions also decreases the nutrient uptake by plants. Proper nutrient management either in the form of Organic manures,
Corresponding Author: Gudikati Shashank Reddy Department of Agronomy, School of Agriculture, Lovely Professional University, Jalandhar, Punjab, India 
chemical fertilizers, bio-fertilizers or by following the integrated nutrient management (INM), the yield can be increased. With short in supply and escalating prices of chemical fertilizers there is an increasing awareness in favour of adopting biological routes of soil fertility management techniques so as to prevent soil degradation and improving the efficiency of applied fertilizers and thus maintaining crop growth. The combination of organic and inorganic sources of nutrients together with biofertilizer have proved good result to use of each component separately. The integrated approach of nutrient supply by chemical fertilizers along with organic manures and biofertilizers is gaining importance and balanced INM involving lower doses of organic materials is needed on priority to enhance the nutrient use efficiency of native and applied nutrients for restoring soil fertility. In this paper, it was discussed about different sources of nutrients and their effect on plant growth and development collecting reviews from various researches done in nutrient management in Bajra.

\section{Use of Organic Manures in Bajra}

FYM, Green Manuring, Vermicompost, Poultry Manure

From P. Chandana's experiment on nutrient management in bajra (P. Chandana et.al; 2018) ${ }^{[8]}$, it was found that organic amendments such as FYM are the major source of organic manures. Higher content of $\mathrm{N}$ is present in poultry manure and can be readily available to crops along with supplying various micro-nutrients (Pratap et al., 2008). Nitrogen that is in available form and that can be easily mineralized is present in pongamia leaves which is an important soil amendment as well as helps for improvement of soil physical properties under dryland agriculture. Another free-living Azotobacter bacteria that can fix nitrogen about $20-40 \mathrm{~kg} \mathrm{~N}$ ha-1 year-1 adding additional plant growth substances can be used as biofertilizers. (Ranveer Singh et al., 2013).

\section{Plant Height}

Nutrients in the early stages are available through inorganic fertilizers and during later stages by both inorganic as well as organic forms decomposition of them makes the higher availability of nutrients helps in increased root development and photosynthetic activity. The concentration of nutrients in pongamia green leaf manure, in poultry manure and FYM differ and is higher in pongamia leaves. with the findings of Amit Kumar et al., (2017), Giribabu et al., (2010) and Dahiya et al., (2008) [3], the increased availability of nutrients due to decomposition and mineralization of organic sources promotes cell elongation and multiplication and thus helps increased shoot growth and plant height of pearl millet over control.

\section{Dry Matter Increase}

Pongamia leaves and inorganic nitrogen added to crops resulted increased number of tillers, maximum leaf area and high photosynthesis which led to accumulation of increased dry matter (Bheemaiah and Subrahmanyam, 2004) ${ }^{[4]}$. Higher uptake of nutrients accelerated the growth of new tissues and development of new shoots thus increased the dry mater accumulation (Ramdev Togas et al., 2017) ${ }^{[10]}$.

\section{Use of Bio Fertilizers}

Experiment conducted at Agronomy Instructional Farm, Sardar krushinagar Dantiwada Agricultural University, Sardarkrushinagar in Kharif - 2009 to study the results of integrated nitrogen management and bio-fertilizer in Kharif pearl millet (Pennisetum glaucum L.) by P.R. PATEL, B.J. PATEL, K.G. VYAS AND B.L. YADAV. Using vermicompost, urea and Azotobacter treatments as nutrient suppliers and their effect on yield of pearl millet was studied. The recommended $\mathrm{N}$ was supplied by using urea and vermicompost $(75 \% \& 25 \%$ respectively) helps increasing the growth and yield of pearl millet. Seed treatment with Azotobacter resulted significantly in increasing the height of plants during harvest and thus yield also. 123 treatments comprised of seven levels of nitrogen management, in three replications using Randomized Block Design with factorial concept were studied. Seed treatment done with $30 \mathrm{~g}$ per $\mathrm{kg}$ of seed. Variety - GHB 558 of bajra was sown on July 5th, 2009 and was harvested on October 3rd, 2009. The observations were recorded on growth and yield determinates of bajra.

\section{Effect of Bio-Fertilizer}

Improvement was found in higher yield attributes viz., plant height, number of effective tillers per plant, length of ear head, girth of ear head, grain yield per plant, test weight and straw yields with Azotobacter inoculation, whereas number of total tillers per plant was found non- significant. There is increased nitrogen availability by fixing atmosphere nitrogen and converting it into available form for plants growth by increasing the production of enzymes like indole acetic acid (IAA), gibberellins (GA), vitamins and also makes balance the microbes in the rhizosphere that help to produce metabolizer to stimulate plant growth and yields were recorded with help of reference from Raghuwanshi et al. (1997) and Bhaghchand and Gautam (2000).

\section{Interaction Effect}

There is significant interaction between nitrogen management and bio fertilizer in case of grain and straw yields on bajra. Application of 100 per cent RDN (75\% through urea and $25 \%$ through vermicompost) along with seed treatment of Azotobacter recorded significant higher grain (2370 kg ha-1) and straw (4396 kg ha-1). The magnitude of increase in grain yield under treatment N3B2 was 161 per cent over lower application of nitrogen N7B1 and in straw 176 per cent yield increase in N3B2 over treatment N6B1 and found the results similar to Satyajeet and Yadav (2006) and Patil and Sheta (2008). Based on the results obtained it is stated that the pearl millet crop if fertilized with $80 \mathrm{~kg} \mathrm{~N}$ ha- 1 through urea along with seed inoculation of Azotobacter it would give higher yields, with this a recommended dose of FYM @ $10 \mathrm{t}$ ha-1 should also be applied uniformly.

\section{Use of Chemical Fertilizers (Singh 2017)}

Mineral fertilization is todays requirement for qualitative and quantitative improving crop yield and its quality following suitable crop management practices (Ali et al., 2008 and Pathak et. al., 2012) ${ }^{[2]}$. Among N, P and k; Phosphorus is a second most nutrient after nitrogen for plant growth and productivity (Vance, 2001) ${ }^{[15]}$. Phosphorous supports flowering, fruiting, root growth, yield and quality components of different crops. For various physiological and metabolic functions of plant, zinc plays an important role (Alam et al., 2010) ${ }^{[1]}$. Next to nitrogen and phosphorus, Zinc stand third among Indian soils (Takkar and Randhawa, 1980), zinc is most deficient among all the micronutrients. From the findings of Lakhan Singh in 2012 at Banaras Hindu University during kharif and his paper published in 2017, phosphorus (30 kg ha-1) and zinc (20 kg ha-1) was found most suitable levels under rain fed conditions for Bajra. 
Increasing doses of phosphorus resulted in reduced zinc uptake and similarly increasing dose of Zinc reduced uptake of phosphorus. It might happen because of antagonistic effect of $\mathrm{P}$ and $\mathrm{Zn}$. Higher concentration of $\mathrm{P}$ in soil from insoluble zinc phosphate which reduces uptake of zinc by grain and straw, eventually reduce the zinc content in grain and straw. The combined effect of phosphorus $\mathrm{x}$ zinc for $\mathrm{N} \& \mathrm{~K}$ content and uptake by grain and straw and protein content in grain were studied. Balanced fertilization programme ensures that fertilizers are applied in adequate amounts and in proportion for optimum plant growth, sustenance of soil and crop productivity. In our country, very little or no potassium is being applied by the farmers and depend on $\mathrm{K}$ reserves in the soil and without external application of $\mathrm{K}$ continuous cropping, it has been reported to cause considerable draining of $\mathrm{K}$ from soil making soil deficit in $\mathrm{K}$ and $\mathrm{N}, \mathrm{K}$ has been reported to be absorbed in large amount than any other nutrients. There was improvement in yields, nutrient uptake of crops with balanced NPK fertilizers (100\% NPK). The yields and uptake of nutrients were significantly reduced in crops with no nutrient treatments over that of $100 \%$ NPK treatment. Nitrogen is the most limiting nutrient and its omission resulted in a drastic reduction in yields of pearl millet and is applicable for most of the crops.

\section{Foliar Feeding}

To increase the productivity in bajra, balanced nutrition is essential (Narolia and Poonia, 2011) ${ }^{[7]}$. Foliar feeding comes under integrated approach and has been accepted as an effective way to compensate soil deficiency and inability of soil to transfer nutrients to the plants to maintain high productivity.

To study the increase in productivity of pearl millet through foliar feeding of N, P and K nutrients in combination with soil application, experiment was conducted at College of Agriculture (SKRAU), (SurgyanRundla and R.C. Bairwa, 2018) ${ }^{[14]}$. The increased nutrient uptake through foliar spray by plants stimulated the rate of physiological processes occurring in plants to increase the yields obtained. To fill the requirement of nutrient deficiency in soil, foliar supplementation of $\mathrm{N}, \mathrm{P}$ and $\mathrm{K}$ helps in boosting the efficiency of food production through enhanced photosynthesis activity and by delaying the leaf senescence promoting the yield parameters of pearl millet. In hybrid RHB-177, Foliar spray of NPK $(18: 18: 18)$ was done at 25 DAS and 35 DAS and urea $(0.5,1.0$ and $1.5 \%)$ at 35 DAS and the highest harvest index $(31.94 \%)$ was recorded with $50 \%$ as basal (NPK) $+1.5 \%$ spray of NPK $(18: 18: 18)$ at 35 DAS.

\section{Integrated Nutrient Management}

To conclude with an approach that could minimize the gap between nutrient demand and supply, to boost the agricultural production, an approach involving chemical fertilizers, organic manures, crop residues and biofertilizer has been studied keeping in view the socioeconomic aspects of farmers. Thus, this serves as mean approach for better livelihood for poor farmers in rain fed areas (Sarkar, 2000). Studies done on use of organic and inorganic fertilizers i.e. FYM, urea, castor cake, gypsum and Azotobacter in bajra by A.H. SIPAI at Agricultural Research Station, Bhachau, Kachchh for three years (2000 to 2006) revealed that the straw yield increased significantly under the treatment of seed treatment with Azotobacter $+60 \mathrm{~kg} \mathrm{~N} / \mathrm{ha}$ over all the treatment combinations tested, except gypsum $5 \mathrm{t} / \mathrm{ha}+80 \mathrm{~kg}$ $\mathrm{N} / \mathrm{ha}$ and $80 \mathrm{~kg} \mathrm{~N} / \mathrm{ha}$ alone in 2003-2004. But in case of remaining years straw yield did not show significant variations. Pooled results of three years indicate that significantly superior straw yield was recorded under the application of seed treatment with Azotobacter $+60 \mathrm{~kg} \mathrm{~N} / \mathrm{ha}$ i.e. $2875 \mathrm{~kg} / \mathrm{ha}$ over other treatment combinations. This might be due to the increased availability of nitrogen and thus leading to more production of carbohydrates and more dry matter production (Rathore and Manohar, 1989) [11]. Azotobacter treatment helps in higher biomass production in plants by increasing the formation of root hairs and lateral roots which help in higher nutrient uptake (Mane et al., 2000) [6].

\section{References}

1. Abedin MJ, Alam MN, Hossain MJ, Ara NA, Haque KMF. Effect of micronutrients on growth and yield of onion under calcareous soil environment. International Journal of Biosciences 2012;2(8):95101.

2. Ali S, Riaz KA, Mairaj G, Arif M, Fida M, Bibi S. Assessment of different crop nutrient management practices for yield improvement. Aust. J Crop Sci 2008;2(3):150-157.

3. Amit Kumar et al. (2017), Giribabu et al. (2010), Dahiya et al. (2008). 'Response of Integrated Nutrient Management on Growth and Yield of Pearlmillet [Pennisetum glaucum (L.) R. Br. emend. Stuntz.]-Wheat (Triticum aestivum L.) Cropping System'. International Journal of Current Microbiology and Applied Sciences. DO- 10.20546/ijcmas.2017.609.168.

4. Bheemaiah G, Subrahmanyam MVR. Growth and yield of groundnut intercropped with Tamarindus indica under different levels of fertility. Indian Journal of Dryland Agricultural Research Development 2004;19(1):94-96.

5. Krishnaprabu S. Influence of Integrated Nutrient Management in Pearl Millet. Int. J. Pure App. Biosci 2018;6(6):508-510.

6. Mane SS, Hadgaonkar AK, Suryawanshi AP, Salunke SD. Response of pearlmillet to inoculation of phosphate solubilizing bacteria and Azosirillum. J. Ind. Soc. Soil Sci 2000;48:617-619.

7. Narolia RS, Poonia BL, Yadav RS. Effect of vermicompost and inorganic fertilizers on productivity of pearl millet (Pennisetum glaucum). Indian Journal of Agriculture Science 2009;79:506-509.

8. Chandana P, Madhavi Lata A, Aariff Kahn MA, Krishna A. Response of nutrient management practices on yield attributes and yield of pearl millet (Pennisetum glaucum L.) under Melia dubiaBased Agri-Silvi System'. Int J Chem Stud 2018;6(4):1127-1130.

9. Chandana P, Madhavi Lata A, Aariff Khan MA, Krishna A. 'Influence of Nutrient Management Practices on Growth and Yield of Pearl Millet in Melia dubia Based Agri-Silvi System'. International Journal of Current Microbiology and Applied Sciences. ISSN: 2319-7706 2018, 7(06).

10. Ramdev Togas, Yadav LR, Choudhary SL, Shisuvinahalli GV. Effect of integrated use of fertilizer and manures on growth, yield and quality of pearl millet. International Journal of Current Microbiology and Applied Sciences. ISSN: 2319-7706 2017;6(8):25102516.

11. Rathore PS, Manohar SS. Response of mustard to nitrogen and sulphur. Indian J. Agron 1989;34(3):328332. 
12. Sarkar AK, Deb DL. Zinc status of rice soils and plants in calcareous belt of north Bihar. J. Indian Soc. Soil Sci 1984;32(2):404-406.

13. Sipai AH, Jat JS, Nakrani BR, Gadhavi, Sharmila. 'Integrated nutrient management in Bajra'. Asian J. Soil Sci 2014;9(1):155-157. e ISSN-0976-7231.

14. Surgyan Rundla, Bairwa RC. 'Response of Foliar Supplementation of N, P and K Fertilizers on Yield and Economics of Pearl Millet'. International Journal of Current Microbiology and Applied Sciences. ISSN: 2319-7706 2018,7(04). DOI: https://doi.org/10.20546/ijc mas.2018.704.133

15. Vance CP. 'Symbiotic nitrogen fixation and phosphorus acquisition, Plant nutrition in a world of declining renewable resource'. Plant Physiology 2001. DOI: https://doi.org/10.1104/pp.010331. 